\title{
Effects of International Financial Integration on Domestic Financial Development in Sub-Saharan African Countries
}

\author{
Lamissa Barro \\ Department of Economics and Management, Université Ouaga II, Ouagadougou, Burkina Faso
}

\begin{abstract}
This paper aims to analyze the effects of international financial integration on the development of domestic financial system in Sub-Saharan Africa, specifically the banking system over the period 2000-2015. The estimation of parameters by system GMM shows that international financial integration is beneficial to the activity and efficiency of the banking system. Moreover, we don't find a breakdown in the relationship, considering only the post-financial crisis period. In addition, the withdrawal of South Africa and Mauritius due to their levels of international financial integration and domestic financial development cancels out the significant effect on the activity and efficiency of the banking system.
\end{abstract}

Keywords: International financial integration, domestic financial development, financial crisis, sub-Saharan Africa

DOI: $10.7176 / \mathrm{JESD} / 10-18-03$

Publication date:September $30^{\text {th }} 2019$

\section{Introduction}

Sub-Saharan Africa (SSA) hasn't been left out of the new configuration of global financial system. Very few countries nowadays impose restrictions on international capital movements, in order to facilitate the international financial integration of their economies. International financial integration, by definition, refers to a country's links with international capital markets.

Furthermore, over the period 2000-2015, the international financial integration index increased from about $150 \%$ to over $300 \%$ of GDP for a sample of 30 SSA countries. Over the same period, there has been some stability in domestic financial development indicators. While international financial integration is now a reality in different parts of the world, the main concern for economists is to assess the consequences for developing countries. Hence the interest for this research to see to what extent international financial integration influences domestic financial development in the African context.

Indeed, the various episodes of financial crises have revived the debate on the potential benefits of international financial integration for the domestic financial sector. Several economists have attempted to establish a causal relationship between the domestic financial sector and international capital markets. Agénor (2003) points out, in particular, that financial openness can increase the depth and development of domestic financial markets and lead to an increase in the degree of financial intermediation, by lowering the excessive costs and benefits associated with monopolistic or cartelized markets.

Mishkin (2009) argues that opening up to foreign financial markets encourages development through easier access to credit, reducing its cost and promoting reforms of the financial system for its proper functioning. In addition, the opening of the capital account exposes domestic financial systems to international competition, improves governance within them and spreads good financial practices. As a result, the intervention of foreign banks can improve the quality of financial services and the efficiency of financial intermediation.

However, it should be noted that unchecked openness can expose the domestic financial system to negative external shocks. Agénor (2003) lists some potential disadvantages associated with the penetration of a foreign bank. First, foreign banks may ration credit to small businesses (which tend to operate in the production of nontradable goods) to a greater degree than domestic banks. Second, the entry of foreign banks, which tend to have lower operating costs, can create pressure and lead to local banks merging in order to remain competitive.

This paper, based on various theoretical developments, attempts to assess the effects of international financial integration on the development of the domestic financial system for a sample of Sub-Saharan African countries. The study attempts, in particular, to highlight a potential structural break that would be a consequence of 20072008 financial crisis. In the following, we first present a synthesis of the theoretical and empirical review. Then, the analysis methodology is presented. Finally, we present the results and comments, followed by a conclusion.

\section{Literature review}

This section is divided into two parts. The first part summarizes the theoretical literature, and the second part presents some empirical evidence.

\subsection{The theoretical developments}

It is increasingly accepted in theory, and confirmed in some empirical work, that the inflow of foreign capital and 
the establishment of foreign banks serve as a catalyst for the development of domestic financial system.

De Gregorio(1999), for example, points out that in the process of integration into international financial markets, countries can benefit from a wide range of risk allocation and financing instruments, as well as risk management institutions, thereby increasing the depth and scope of domestic financial systems. For this author, observation based on de facto indicators of the degree of financial integration shows that emerging countries and low-income countries (LICs) that are financially better integrated have deeper banking sectors than LICs and emerging countries that are less integrated into international markets.

Levine (1996) and Claessens et al (2001) essentially put forward three reasons for mentioning the importance of international financial integration in the development of domestic financial systems. First, they argue that openness increases the likelihood of access to international capital markets. Second, the removal of entry restrictions on foreign banks improves the quality and accessibility of financial services; it brings greater competitiveness and competition in domestic financial markets, promotes the application of modern banking practices, management and technology in the domestic financial system. Finally, the opening to foreign banks encourages the adoption of better policies and the establishment of financial infrastructure to stabilize the financial system.

Similarly, Stulz (1999) argues that the presence of barriers to international investment leads to segmentation between domestic and foreign capital markets. This obliges local investors to bear all the risks associated with the economic activities of their country of residence. This lack of diversification can lead actors to reduce their risk taking. It should be recalled that the reason for portfolio risk diversification is one of the main arguments put forward by economists in favour of international financial integration policies. To reduce the risk of portfolio, it is better to invest diversifier your investments rather than invest all the wealth in a single asset. International exchanges provides access to a wider range of financial assets according to Markovitz (1952) and Tobin(1958).

For Berger et al (2000), foreign banking institutions, which are generally large banks, come to establish themselves with greater expertise. National institutions use technology diffusion to expand their products and improve the quality of their services. However, these national banks, in line with the efficiency and competitiveness standards imposed by international banks, are obliged to reduce profit margins in order to maintain their customer base and market share (Allégret and Azzabi, 2014). This strategy has potentially positive impacts on the quality and availability of financial services. Similarly, because of their familiarity with more advanced financial systems, foreign financial firms are likely to increase pressure on local government to implement reforms that enable the financial system to operate more efficiently (Mishkin, 2009). Kose et al (2006) argue that international financial integration appears to be a real catalyst for the domestic financial system in developing countries. The challenge in these countries remains access to diversified financial services, the stability of the financial system through better regulation and supervision, which is facilitated by the establishment of foreign banks and access to international capital markets. In addition, the presence of foreign financial institutions can be seen as an assurance to those who may be concerned about the solvency of domestic banks.

To summarize, for Kose et al (2006), the more foreign banks are established in a country, the better the quality of financial services and the more efficient financial intermediation is. As for securities markets, the most common theory is that the arrival of foreign companies increases their efficiency. Once liberalized, stock markets tend to become larger and more liquid.

The narrowness of the financial markets in developing countries has for a long time been considered as a real handicap for their development. International financial integration, through these effects on the domestic financial sector, is expected to positively impact the real sector through stronger and sustained growth.

\subsection{Some empirical evidence}

In the empirical literature, very few authors have analyzed the relationship between international financial integration and domestic financial development alone. Some of those who have been interested in it are studying the impact of foreign bank penetration on domestic banks, while others are studying the impact of the opening of capital account on the development of stock markets.

Lensink and Hermes (2003) study the short-term effects of foreign bank entry on the behaviour of the domestic banking sector. They provide an econometric analysis based on bank data from 48 countries for the period 1990-1996, assuming that these effects depend on the level of economic development of the host country. Their results show that at low levels of economic development, foreign bank entry is generally associated with higher costs and margins for domestic banks. At higher levels of economic development, the effects seem less obvious: foreign bank entry is associated with either lower domestic bank costs or no change in these variables. However, it should be stressed that this analysis is valid for the short term. In the long term, the entry of foreign banks combined with the implementation of new financial services, technologies and practices can lead to lower costs and lower bank margins.

Furceri et al (2012) analysed the effect of foreign capital inflows on the evolution of domestic credit. Using data from developed and emerging economies from 1970 to 2007, they showed that in the two years following the 
start of a capital inflow surge, the credit-to-GDP ratio increased by about $2 \%$; the effect was reversed in the medium term, with a credit-to-GDP ratio declining by nearly 4\% seven years after the initial surge. The study also shows that the effect is different depending on the type of flow characterizing the episode (debt or FDI); capital flows generated by debt having the largest effect. The results of the study also suggest that the short-term effect of foreign capital flows on domestic credit depends on the macroeconomic policies of host countries. In particular, this effect is weaker in countries with higher real exchange rate flexibility and counter-cyclical fiscal policy. Thus, the choice of the ARDL estimation method allowed the authors to better understand the dynamics of the relationship between foreign capital inflows and domestic credit. The reversal of medium-term effects could be due to the highly unstable and pro-cyclical nature of some types of capital (notably debt securities).

Frey and Volz (2013) provide an analysis of the costs and benefits of regional financial integration (RFI) for the financial systems of sub-Saharan African countries. The authors essentially tested two hypotheses. The first hypothesis states that regional financial integration involves financial development; the second hypothesis indicates that it has negative effects on the financing conditions of small businesses. The results suggest that the RFI improves the size of the financial sector if a certain level of institutional quality is achieved. If such a level of institutional quality is lacking, the effect is negative. However, this result only applies to the ratio of liquid liabilities to GDP, a very broad measure of the size of the financial sector. A significant influence of the RFI on the ratio of private credit to GDP or the efficiency of the banking sector have not been identified by the authors.

With regard to the effects of the RFI on the access and financing costs of small businesses in sub-Saharan Africa, the same study yields rather mixed results. While the IFR has a positive and significant effect on the credit constraints measured by the subjective valuation of small firms, it does not appear to have any effect on the credit constraints measured in terms of the costs of financing small firms. In addition, there is a positive and significant influence of foreign bank participation on the severity of credit constraint for small firms, but a negative effect on their financing costs. These results can be interpreted as an indication of the exclusion of small firms from the credit market, following the penetration of large foreign banks, supporting the thesis of Agénor (2003) for whom, foreign banks are more turned towards the financing of large companies that usually officiate in the production of tradable goods. While this study may offer interesting results in terms of analysis, it should be noted that its limit may lie in the regional financial integration (RFI) indicator used. Indeed, the authors use a de jure RFI indicator based on treaties and bilateral agreements, to the detriment of a de facto indicator that they justify by the unavailability of data on bilateral capital flows in Sub-Saharan Africa.

Lane and McQuade (2014) study the relationship between international capital movements and domestic credit growth for a group of 30 European countries over 1993 - 2008. These authors use debt flows and net equity capital flows as indicators of international financial integration. They conclude that international financial integration, through debt flows, helps to promote the development of the domestic financial sector measured by domestic credit growth, in contrast to net equity capital flows have no significant effect.

Asongu and De Moor (2015) analyse the effects of financial globalization, represented by net inflows of foreign direct investment as a percentage of GDP (FDI / GDP), on financial development measured by his depth, efficiency and activity. They use data covering 53 African countries over the period 2000-2011. The results obtained indicate that, first of all, the FDI / GDP thresholds at which financial globalization increases the money supply are respectively 20.50 and 16.00 for below and above-median sub-samples of financial globalization. Second, the FDI / GDP thresholds from which financial globalization increases banking system activity and financial system activity for below-median sub-samples of financial globalization are 13.81 and 13.29 respectively. The importance of the study is that it highlights the thresholds at which foreign capital flows are conducive to domestic financial development.

\section{Model and Econometric Issues}

We present in this section the econometric model, the variables and the estimation method.

\subsection{Model and variables}

Following the previous work (De Gregorio, 1999) ; Furceri et al, 2012) on the issue, the relationship between the degree of international financial integration and the level of financial development can be in the form of : $D F=f(I F I, X)$, where $I F I$ is the indicator of international financial integration and $X$ a matrix of variables that can influence the level of financial development. By postulating for a linear relation, according to the previous literature, the model can be written in the following form :

$D F_{i, t}=\beta_{0}+\beta_{1} I F I_{i, t}+\delta D F_{i, t-1}+\beta_{2}^{\prime} X_{i, t}+\varepsilon_{i, t}$

The variables of the equation (1) are as follows :

$\checkmark$ Financial Development (DF) : This is the dependent variable. Here, three financial development indicators are selected to take into account the different characteristics (activity, size and efficiency). These data are taken from Beck et al, 2000. The countries of sub-Saharan Africa have the main characteristic of having 
financial systems mainly dominated by banks, hence the limited interest in the development of the banking system.

$\checkmark \quad$ International Financial Integration Indicator (IFI) : this is the explanatory variable of interest. As international financial integration indicators, we retain a de facto measure (Lane and Milesi-Ferretti, 2017) : it is the sum of total assets and liabilities as a percentage of GDP. We prefer a de facto measure of financial integration, since de jure indicators are often criticized for not always reflecting reality. Indeed, a country can liberalize its capital account and not attract foreign capital. According to the literature, the expected sign of these indicators on financial development is ambiguous.

The matrix $\mathrm{X}$ of the control variables is composed as follows :

$\checkmark \quad$ Real GDP per capita : This variable is used to report the effects of the country's economic performance on the development of the financial system. A positive coefficient is expected.

$\checkmark \quad$ Inflation rate : this is an indicator of macroeconomic stability. Taking this into account allows one to see how the macroeconomic environment could affect the financial environment. The expected sign of the coefficient is negative. Indeed, according to the literature, a strong inflation deteriorates the position of creditors, and can negatively affect the efficiency of the banking system.

$\checkmark$ Public expenditure : it is an instrument of State policy. According to Keynesian theory, public interventions can boost economic activity, contributing to job creation and additional income ; anything that could create opportunities for the financial sector. It is expected a positive sign.

$\checkmark \quad$ Trade opening : it is given by the sum of exports and imports relative to GDP. It is expected a positive sign. Indeed, the absence of restrictions on trade can encourage the financial sector to engage in financing of the tradable goods production.

$\checkmark$ Human capital measured by the gross primary school enrollment rate. The consideration of this variable is based on the assumption that education is a good vehicle for financial reporting, and thereby contributes to financial inclusion. The expected sign is therefore positive.

All control variables are extracted from the database of the African Development Bank (AfDB Socio Economic Database)

\subsection{Estimating technique}

We use the System Generalized Moment Method (S-GMM) for the estimation of equation parameters. This method is adequate to solve the problem of endogeneity of one or more explanatory variables, in particular the presence of the delayed dependent variable which gives a dynamic character to the panel specification. There are, however, two GMM-related estimators : the difference estimator (Arellano and Bond, 1991) and the system estimator (Blundell and Bond, 1998) which is an improved version of the first one. The system estimator by Blundell and Bond (1998) simultaneously uses first-difference equations and those in levels, and is more efficient than the firstdifference GMM estimator developed by Arellano and Bond (1991). Differentiation makes it possible to eliminate the country-specific effect and consequently the bias of time-invariant omitted variables. The first differences in the potentially endogenous explanatory variables are instrumented by their lagged level values, in order to reduce the simultaneity bias as well as the inverse causality bias, and under the assumption of no autocorrelation of the errors in the level equation. These orthogonality conditions can be expressed as follows :

$$
\begin{aligned}
& E\left[Y_{i t-s}\left(\varepsilon_{i t}-\varepsilon_{i, t-1}\right)\right]=0 \text { for } s \geq 2 \text { and } t=3, \ldots, T \\
& E\left[X_{i t-s}\left(\varepsilon_{i t}-\varepsilon_{i, t-1}\right)\right]=0 \text { for } s \geq 2 \text { and } t=3, \ldots, T
\end{aligned}
$$

Where $\mathrm{X}$ is the matrix of explanatory variables.

However, the loss of information related to the estimation of the first difference model (by eliminating the individual specific effects) can alter the robustness of the GMM difference estimator, because of the level instruments that are often weakly correlated with their difference value (Blundell and Bond, 1998). These authors theoretically propose that this problem can be solved by combining instruments in level with those in difference. As a result, Blundell and Bond (1998) propose the following system of equations, combining the first difference model and the level one :

$$
\left\{\begin{array}{c}
\Delta Y_{i t}=\pi \Delta Y_{i, t-1}+\beta^{\prime} \Delta X_{i t}+\Delta \lambda_{t}+\Delta \varepsilon_{i t} \\
Y_{i t}=\pi Y_{i, t-1}+\beta^{\prime} X_{i t}+u_{i}+\lambda_{t}+\Delta \varepsilon_{i t}
\end{array}\right.
$$

Where $Y$ is the dependent variable; $X$ the matrix of explanatory variables; $u_{i}$ and $\lambda_{t}$ the individual and temporal fixed effects respectively; $\beta$ and $\pi$ are parameters to estimate

\section{Main results and discussions}

In a first time, we make a descriptive and graphical analysis, and in a second time, we comment on the econometric results. 


\subsection{Descriptive and graphical analyzis of the data}

Table 1 presents the descriptive statistics of data.

Table 1 : Descriptive statistics.

\begin{tabular}{lllll}
\hline variables & Average & Standard deviation & Minimum & Maximum \\
\hline Financial integration & 229.82 & 868.10 & 31.70 & 7864.78 \\
Credit to the private sector & 20.80 & 26.21 & 0.55 & 150.21 \\
Total Bank Assets & 77.09 & 19,91 & 8.88 & 100.00 \\
Net interest margin & 6.95 & 3.38 & 0.62 & 39.24 \\
Real GDP per capita & 953.58 & 1352.25 & 85.82 & 6199.00 \\
Trade outside & 66.51 & 24.61 & 19.24 & 158.61 \\
Public expenditure & 14.40 & 5.78 & 0.01 & 51.28 \\
Inflation & 11.08 & 34.25 & -48.39 & 550.00 \\
Primary school enrollment rate & 99.32 & 23.89 & 32.94 & 149.95 \\
\hline
\end{tabular}

The average of financial integration is around $230 \%$ of GDP over the period $2000-2015$. The maximum level (7864\%) is registered in Mauritius in 2010. This island has the characteristic of a financial center where important international transactions are made, especially with the multinationals. Moreover, the level of domestic financial development remained relatively low, with an average credit to private sector of $20.8 \%$ of GDP; the maximum $(150 \%)$ is reached in South Africa in 2007. This Country stands out from the crowd relatively to its level of financial development. It also has a low net interest margin on average (3.76\%), compared to the regional average $(6.95 \%)$; which indicates a greater efficiency of its financial system. Thus, it appears that, given their degree of international financial integration and financial development, Mauritius and South Africa may present outliers, which may lead to selection bias. It would be interesting to consider another analysis that excludes both countries.

Graph 1 presents the evolution of international financial integration and financial development indicators over the period 2000-2015 for a group of 30 countries of sub-Saharan Africa.

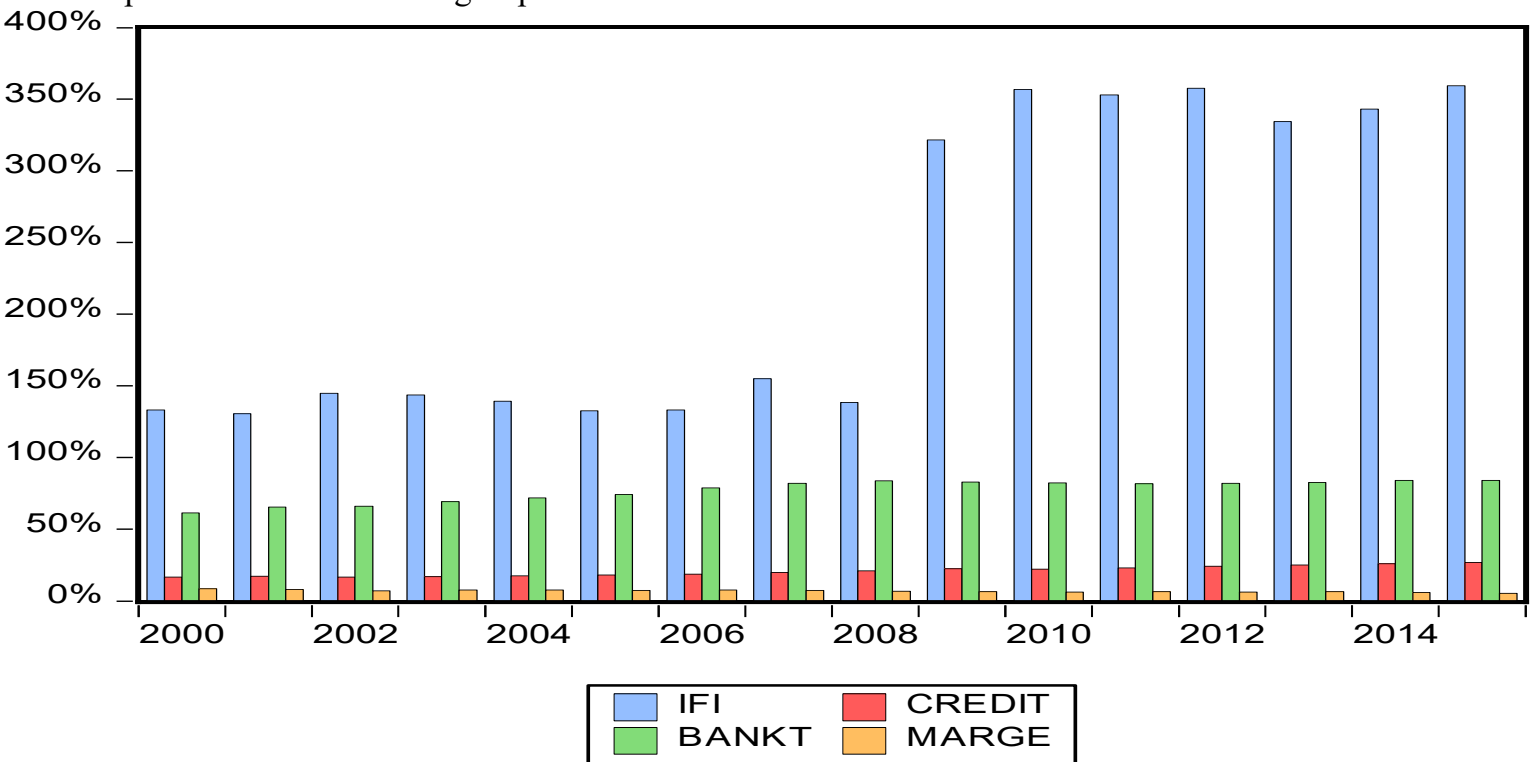

Graph 1 : Evolution of financial integration and financial development over the period 2000 - 2015 (sample of 30 SSA countries)

It can be seen that during the period, domestic financial development indicators (credit to the private sector, total bank assets and net margin) varied very little. In addition, the degree of international financial integration has two phases. A first phase, from 2000 to 2008, shows a low degree of integration that is around 150\% of GDP, and a second phase from 2009 to 2015 with a remarkable increase. This finding can be justified by the fact that the African continent was one of regions of the world less affected by the 2007-2008 financial crisis. In the aftermath of this crisis, international capital, in search of new opportunities rushed to this continent. However, the analysis of the phenomenon of international financial integration must be made with great attention, especially with the presence in the sample of a country like Mauritius that can be described as an financial center " offshore ». The financial centers, for the most part " offshore ", conduct most of their activities with non-residents (both on the assets and liabilities side of the balance sheet). The activities, which are mainly or exclusively international, benefit from exceptional regulations, and outstanding external receivables and liabilities are irrelevant to the financial intermediation needs of the domestic economy.

In order to deduce the influence of some economies on the degree of international financial integration of the 
sample, we make a representation that excludes Mauritius and South Africa (graph 2 in the Appendix). These two countries have relatively high degrees of financial integration and financial development compared to other countries. For the other countries, we can note a lower level of financial development (credit to the private sector on average of $14.6 \%$ of GDP) and a lower degree of financial integration (on average $110 \%$ of GDP). The dynamic also highlights two phases of financial integration over the period. In particular, we note a decline from 2000 to 2008 , with a slow recovery from 2009 , compared to the previous graph. The same conclusions can be drawn.

\subsection{Econometric results and discussions}

We present the estimates in three different tables. An initial estimate is made for a global sample of 30 Sub-Saharan African countries over the period 2000 to 2015, depending on the availability of data. A second estimate is made over the period 2010 to 2015 to note a possible break after the financial crisis of 2007-2008. Finally, we make one last estimate excluding Mauritius and South Africa, which have fairly high levels of financial development and financial integration compared to other countries in the sample. In all cases, the null hypothesis of the secondorder Arellano and Bond autocorrelation test $(\operatorname{AR}(2))$ in difference for the absence of autocorrelation in the residuals should not be rejected. Furthermore, the Sargan over-identification restrictions tests should not be significant because their null hypotheses are the positions that instruments are valid or not correlated with the error terms.

Results of the first estimate (Table 2), reveal that international financial integration has a positive and significant effect at $10 \%$ on the activity of banking system, measured by the credicts to private sector. A $1 \%$ increase in financial integration is accompanied by an increase of $0,1 \%$ of the credit ratio. These results partly corroborate those found by Furceri et al (2012), who find a positive effect of financial integration on the activity of domestic financial intermediaries. However, it appears that international financial integration does not have a significant effect on the size of financial intermediaries, as measured by the total assets of the deposit banks relative to the sum of these assets with those of the central bank. Finally, international financial integration has a significant effect on the efficiency of the domestic banking system, measured by net interest margins of banks. Financial integration negatively affects net interest margins at the significance level of $1 \%$. It thus appears that the net margins of banks decrease with the opening of the capital account, and the influx of foreign capital; anything that contributes to improving the efficiency of the domestic financial system.

Table 2 : International Financial Integration and Financial Development in SSA (2000-2015)

\begin{tabular}{llll}
\hline Variables & Credit & Total assets & Net margin \\
\hline Financial integration & $\mathbf{0 . 1 0 6 *}$ & $\mathbf{- 0 . 0 9 3 1}$ & $\mathbf{- 0 . 1 0 6 * * *}$ \\
Trade & $(0.0564)$ & $(0.0570)$ & $(0.0323)$ \\
Public expenditure & -0.152 & -0.106 & 0.143 \\
& $(0.118)$ & $(0.0881)$ & $(0.126)$ \\
GDP per capita & $0.108 * *$ & $0.0462 * *$ & $-0.0421^{*}$ \\
& $(0.0528)$ & $(0.0207)$ & $(0.0250)$ \\
Primary school enrollment & $0.205 *$ & $0.240 *$ & $-0.111 * *$ \\
& $(0.109)$ & $(0.137)$ & $(0.0473)$ \\
Inflation & 0.129 & 0.0144 & $0.353 *$ \\
& $(0.0800)$ & $(0.0964)$ & $(0.180)$ \\
Credit (-1) & $-0.467 * *$ & 0.0719 & -0.111 \\
& $(0.201)$ & $(0.171)$ & $(0.234)$ \\
Total bank assets (-1) & $0.506 * *$ & & \\
Net interest margin (-1) & $(0.242)$ & & \\
Constant & & 0.377 & $(0.235)$ \\
Observations & & & $0.231 * *$ \\
Number of countries & & 1.568 & $(0.106)$ \\
Number of instruments & $1.499 *$ & $(1.379)$ & 0.998 \\
AR (2) - Probability & $(0.835)$ & 449 & $(1.188)$ \\
Sargan - Probability & 449 & 30 & 349 \\
\hline Ne $:$ Al varabs & 30 & 0.177 & 22 \\
& 22 & 1.000 & 0.675 \\
& 0.277 & 0.930 & 0.609 \\
\hline
\end{tabular}

Note : All variables are taken in logarithm. The Sargan test is associated with the null hypothesis of validity of the instruments ; the AR (2) test is associated with the null hypothesis of no second-order serial correlation of difference errors. Values in parentheses are standard errors ; *** significant at $1 \%$, ** significant at $5 \%$, * significant at $10 \%$. 
These results are confirmed when the analysis is done over the period 2010 - 2015 (Table 3). The 2007-2008 financial crisis does not seem to mark a break in the relationship between the African domestic financial system and international capital markets. This could be explained by the fact that very few African countries have suffered of negative effects of this crisis, but also by the relatively low level of integration of these countries in international capital markets.

Table 3 : International Financial Integration and Financial Development in SSA (2010-2015)

\begin{tabular}{llll}
\hline Variables & Credit & Total assets & Net margin \\
\hline Financial integration & $\mathbf{0 . 0 8 9 2}$ & $\mathbf{0 . 0 2 3 1}$ & $\mathbf{- 0 . 0 9 0 7 * *}$ \\
Trade & $(0.0484)$ & $(0.0246)$ & $(0.0456)$ \\
& -0.0404 & -0.0132 & 0.190 \\
Public expenditure & $(0.0694)$ & $(0.0221)$ & $(0.122)$ \\
& $0.186 *$ & $0.0988 * * *$ & -0.0643 \\
Real GDP per capita & $(0.107)$ & $(0.0207)$ & $(0.0968)$ \\
& 0.0665 & 0.00623 & -0.0344 \\
Primary school enrollment & $(0.0416)$ & $(0.0512)$ & $(0.0361)$ \\
& 0.0678 & $0.0594 * * *$ & 0.336 \\
Inflation & $(0.0650)$ & $(0.0154)$ & $(0.252)$ \\
& -0.253 & $-0.582 * * *$ & $0.824 *$ \\
Credit (-1) & $(0.170)$ & $(0.0607)$ & $(0.489)$ \\
Total bank assets $(-1)$ & $0.699 * * *$ & & \\
Net interest margin $(-1)$ & $(0.147)$ & & \\
Constant & & $0.390 * * *$ & $(0.0510)$ \\
observations & & & $0.560 * *$ \\
Number of countries & & & $(0.227)$ \\
Number of instruments & 0.616 & $4.777 * * *$ & $4.660 * *$ \\
AR (2) & $(0.861)$ & $(0.411)$ & $(1.956)$ \\
Sargan & 150 & 150 & 150 \\
Note: All variabs & 30 & 30 & 30 \\
& 12 & 17 & 12 \\
& 0.107 & 0.499 & 0.330 \\
& 0.945 & 0.216 & 0.120 \\
\hline
\end{tabular}

Note : All variables are taken in logarithm. The Sargan test is associated with the null hypothesis of validity of the instruments ; the AR (2) test is associated with the null hypothesis of no second-order serial correlation of difference errors. Values in parentheses are standard errors ; *** significant at $1 \%$, ** significant at $5 \%$, * significant at $10 \%$.

However, by removing South Africa and Mauritius from the sample, the results differ significantly (Table 4). International financial integration is now meaningless to explain the activity and efficiency of the banking system. In addition, financial integration appears to negatively and significantly impact the size of the financial system. It appears from these results that, the level of financial development on the one hand, and the degree of international financial integration on the other and, can play a key role in explaining the relationship studied. Indeed, South Africa and Mauritius have private sector credit ratios in the order of $137 \%$ and $76 \%$ of GDP respectively, compared to a sample average of $20 \%$ of GDP. The degree of international financial integration is respectively $171 \%$ and $3629 \%$ of GDP for South Africa and Mauritius. There may therefore be threshold effects in the relationship between international financial integration and the development of the domestic financial system. 
Table 4 : International Financial Integration and Financial Intermediation in SSA (2000-2015), Mauritius and South Africa Excluded

\begin{tabular}{llll}
\hline Variables & Credit & Total assets & Net margin \\
\hline Financial integration & $\mathbf{0 . 0 0 3 3 6}$ & $\mathbf{- 0 . 0 6 2 7 *}$ & $\mathbf{- 0 . 0 8 4 1}$ \\
Trade & $(0.0483)$ & $(0.0365)$ & $(0.0690)$ \\
& -0.101 & -0.0974 & 0.134 \\
Public expenditure s & $(0.113)$ & $(0.129)$ & $(0.130)$ \\
& $0.127 *$ & $0.0563 * * *$ & -0.0368 \\
Real GDP per capita & $(0.0727)$ & $(0.0191)$ & $(0.0250)$ \\
& 0.177 & 0.220 & $-0.0838^{*}$ \\
Primary school enrollment & $(0.110)$ & $(0.176)$ & $(0.0463)$ \\
& 0.191 & 0.0434 & $0.316^{*}$ \\
Inflation & $(0.123)$ & $(0.100)$ & $(0.178)$ \\
& $-0.576 *$ & 0.0264 & -0.130 \\
Credit (-1) & $(0.294)$ & $(0.156)$ & $(0.238)$ \\
& 0.327 & & \\
Total bank assets (-1) & $(0.385)$ & & \\
Net interest margin $(-1)$ & & 0.351 & $(0.226)$ \\
Constant & & & $0.275 * *$ \\
observations & & & $(0.111)$ \\
Number of countries & 2.517 & 1.694 & 0.943 \\
Number of instruments & $(1.535)$ & $(1.326)$ & $(1.278)$ \\
AR (2) & 419 & 419 & 419 \\
Sargan & 28 & 28 & 28 \\
Note: All variabs & 35 & 22 \\
& 22 & 0.181 & 0.644 \\
& 0.531 & 1.000 & 0.735 \\
\hline
\end{tabular}

Note : All variables are taken in logarithm. The Sargan test is associated with the null hypothesis of validity of the instruments ; the AR (2) test is associated with the null hypothesis of no second-order serial correlation of difference errors. Values in parentheses are standard errors ; *** significant at $1 \%$, ** significant at $5 \%$, * significant at $10 \%$.

Other variables appear decisive for explaining the development of the domestic financial system in the countries of sub-Saharan Africa. Public expenditure and real GDP per capita have positive and significant effects, in line with the expected signs.

\section{Conclusion}

Sub-Saharan African countries have, in recent decades, embarked on a process of liberalization of their capital accounts in order to reap the benefits of international financial integration. In this paper, we have specifically analyzed the effects of international financial integration on the development of the domestic financial system. Given the configuration of the financial systems of Sub-Saharan African countries dominated by banks, the analysis focused on the development of the banking system. Our analysis shows that international financial integration is conducive to the activity and efficiency of the banking system. Moreover, we do not record a break in the relationship, considering only the period after the 2007-2008 financial crisis. In addition, the withdrawal of South Africa and Mauritius due to their levels of international financial integration and financial development cancels the significant effect on the activity and efficiency of the banking system.

These results teach that international financial integration can create opportunities for the development of the domestic financial system, and play a complementary role in financing the economies of Sub-Saharan Africa. This relationship would be more evident if certain levels of international financial integration and domestic financial development are achieved. In perspective, the study could be extended by taking into account potential threshold effects.

\section{References}

Agénor, P. R. (2003). Benefits and costs of international financial integration : theory and facts. The World Economy, 26 (8), 1089-1118.

Allegret, J. P., \& Azzabi, S. (2014). Intégration Financière Internationale et Croissance économique dans les pays émergents et en développement : Le canal du développement financier. Revue d'économie du développement, Vol. 22, 27-68.

Arellano, M., \& Bond, S. (1991). Some tests of specification for panel data: Monte Carlo evidence and an 
application to employment equations. The Review of Economic Studies, 58, 277 - 297.

Arellano, M., \& Bond, S. (1991). Some tests of specification for panel data: Monte Carlo evidence and an application to employment equations. Review of Economic Studies 58, 277-297.

Asongu, S. A., \& De Moor, L. (2015). Financial globalisation dynamic thresholds for financial development: evidence from Africa. Yaoundé, Cameroon: African Governance and Development Institute.

Beck, T., Demirgüç-Kunt, A., \& Levine, R. (2000). A New Database on Financial Development and Structure. World Bank Economic Review 14, 597-605.

Berger, A. N., Robert, D., Hesna, G., \& Gregory, F. U. (2000). Globalization of Financial Institutions: Evidence from Cross-Border Banking Performance. Brookings-Wharton Papers on Financial Services, Vol. 3.

Blundell, R., \& Bond, S. (1998). Initial conditions and moment restrictions in dynamic panel data models. Journal of Econometrics 87, 11-143.

Claessens, S., Demirgüç-Kunt, A., \& Huizinga, H. (2001). How does Foreign entry affect domestic banking markets? Journal of Banking \& Finance (25), 891-911.

De Gregorio, J. (1999). Financial integration, financial development and economic growth. Estudios de Economia, $137-161$.

Frey, L., \& Volz, U. (2013). Regional financial integration in Sub-Saharan Africa: an empirical examination of its effects on financial market development. South African Journal of Economics Vol. 81:1 , 79-117.

Furceri, D., Guichard, S., \& Rusticelli, E. (2012). The effect of episodes of large capital inflows on domestic credit. North American Journal of Economics and Finance 23, 325-344.

Kose, M. A., Prasad, E. S., Rogoff, K., \& Wei, S. J. (2006). Financial Globalization: A Reappraisal. IMF Working Paper, WP/06/189, International Monetary Fund.

Lane, P. R., \& McQuade, P. (2014). Domestic credit growth and international capital flows. Scandinavian Journal of Economics 116(1), 218-252.

Lane, P. R., \& Milesi-Ferretti, G. M. (2017). International Financial Integration in the Aftermath of the Global Financial Crisis. IMF Working Paper.

Lensink, R., \& Hermes, N. (2003). Foreign Direct Investment, Financial Development and Economic Growth. Journal of Development Studies, 40, 142-163.

Levine, R. (1996). Foreign Banks, Financial Development, and Economic Growth. International Financial Markets: Harmonization versus Competition (pp. 224-254). Washington: AEI Press.

Markovitz, H. M. (1952). Portfolio Selection. Journal of Finance, 7 (1), 77-91.

Mishkin, F. S. (2009). Globalization and financial development. Journal of Development Economics, 164-169.

Stulz, R. M. (1999). Globalization, Corporate Finance, and the Cost of Capital. Journal of Applied Corporate Finance, VOL UME 1 2. 3, 1-25.

Tobin, J. (1958). Liqui-dity Preference as Behavior toward Risk. Review of Economic Studies, 25, 65-86.

\section{Appendix}

Table 5 : List of Countries in the sample (30)

\begin{tabular}{llll}
\hline Angola & Ivory Coast & Mali & South Africa \\
Benign & Ethiopia & Mauritius & Sudan \\
Botswana & Gabon & Mozambique & Tanzania \\
Burkina Faso & Ghana & Namibia & Togo \\
Burundi & Guinea & Niger & Uganda \\
Cameroon & Kenya & Nigeria & Zambia \\
Chad & Madagascar & Rwanda & \\
Congo, Dem . Rep. of & Malawi & Senegal & \\
\hline
\end{tabular}




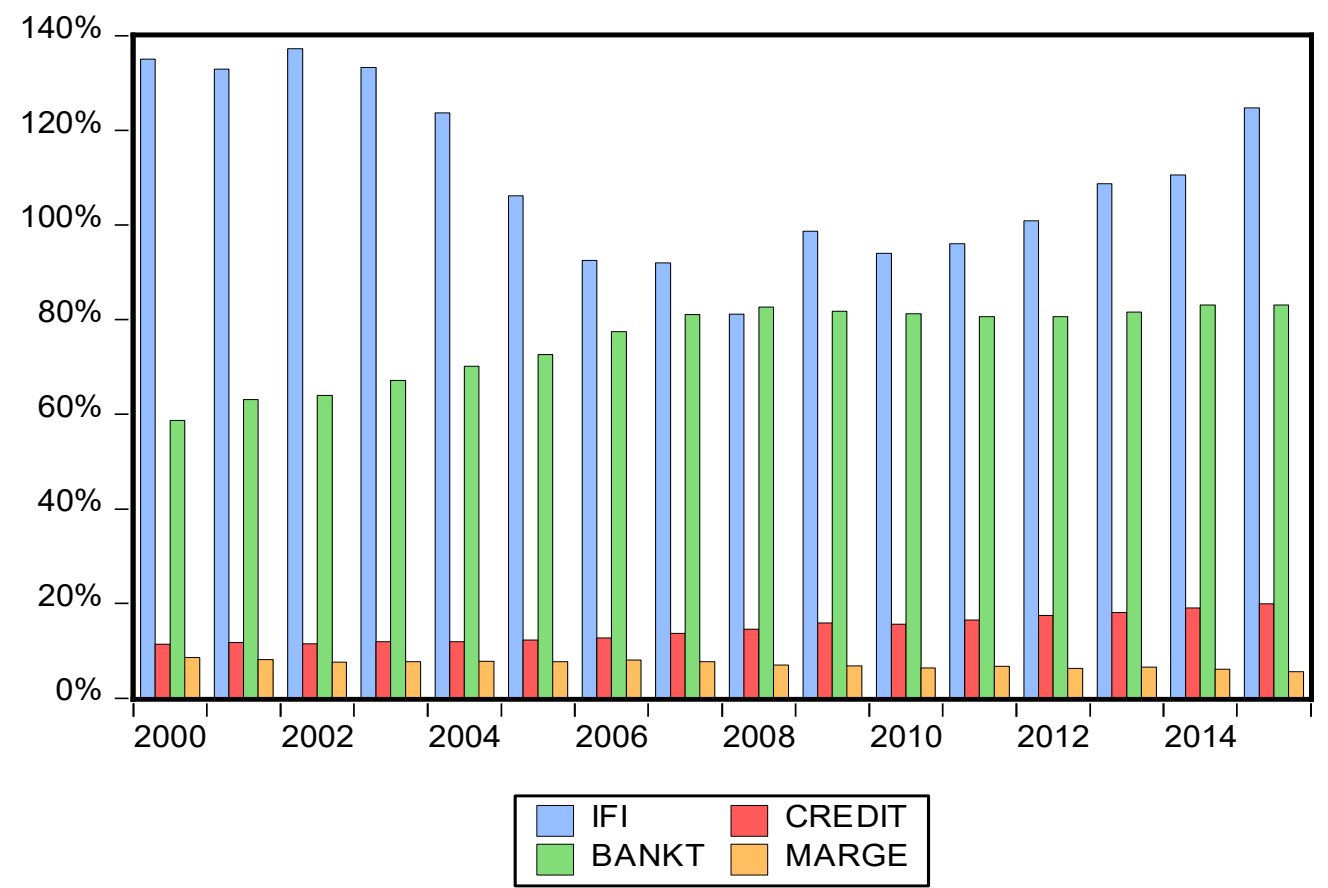

Graph 2 : Evolution of financial integration and financial development over the period 2000-2015 (excluding South Africa and Mauritius) 